DOI: $10.15642 / J I I S .2014 .8 .1 .1-22$

\title{
THE ROOTS, STRATEGIES, AND POPULAR PERCEPTION OF ISLAMIC RADICALISM IN INDONESIA ${ }^{\top}$
}

\author{
Akh. Muzakki \\ UIN Sunan Ampel, Surabaya - Indonesia | akh.muzakki@yahoo.com
}

\begin{abstract}
This paper examines Islamic radicalism particularly in Indonesia in terms of its roots and strategies of action. While focusing on the Jama'ah Islamiyah (JI, lit. "Islamic Community") as the larger subject of discussion, it takes Ar Rahmah Media Network with its print publication of Jihad Magazine (Jihadmagz) in particular as the case of study. The paper argues that the emergence of Islamic radicalism is mainly triggered by the combination of the ruling regime's political repression, crucial socio-economic deprivation, globalisation, and Arabia support. Also, it further argues that there is a shift of strategies among activists of radical Muslims in delivering their messages as well as in conducting their radical actions.
\end{abstract}

Keywords: Radicalism, Islamic radicalism, jïhäd, Jama'ah Islamiyah

\section{Introduction}

Southeast Asian Islam has recently been exposed to a problem of Islamic radicalism. Within the Southeast Asia region, the issue of Islamic radicalism has been given a wide coverage by media. A large percentage of the Muslim population of the world lives in this region, and thus Islamic radicalism is an issue of immense significance in the region. Certainly, al-Qaeda, which is regarded as the number one Islamic terrorist group in the world, is not based in the region. However, it has been suggested that al-Qaeda has links with other radical groups in the region - groups said to be responsible for the

\footnotetext{
1 The earlier version of this paper was first presented to the international conference "Tolerance and Intolerance: Rethinking Interfaith Relation in Indonesia" organsied by Sekolah Tinggi Agama Islam Negeri (STAIN, State Islamic College) Tulungagung in Tulungangung - Indonesia, 20 November 2010.
} 
bomb attacks in the Philippines, Singapore, Malaysia, and Indonesia. Since Islamic radicalism has drawn the attention of the world, Southeast Asian Islam also becomes a subject of scholarly discussion.

This paper examines Islamic radicalism particularly in Indonesia in terms of its roots and strategies of action. While focusing on the Jama'ah Islamiyah (JI, lit. "Islamic Community") as the larger subject of discussion, it takes Ar Rahmah Media Network with its print publication of Jihad Magazine (Jihadmagz) in particular as the case of study. The paper argues that the emergence of Islamic radicalism is mainly triggered by the combination of the ruling regime's political repression, crucial socio-economic deprivation, globalisation, and Arabia support. Also, it further argues that there is a shift of strategies among activists of radical Muslims in delivering their messages as well as in conducting their radical actions.

To begin with, the paper explores the roots of Islamic radicalism in Indonesia. In what follows, it discusses the shift of local people's perception of Islamic radicalism. Central to the discussion of this shift are the popular responses towards Islamic radicalism, particularly the issue of the existence of JI in Indonesia and the radical, violent actions by activists of this group. At the end, the paper investigates the diverse strategies the activists of radical Muslims shift from one time to another in delivering their messages to wider audience.

The paper argues that Islamic radicalism is not a make-up story in Southeast Asia, particularly Indonesia. In an earlier phase, it further argues, local people of the country split into diverse kinds of perception about Islamic radicalism. One striking perception was the doubt of the existence of radical Muslim groups, particularly JI. The success of the police in chasing the perpetrators of violent actions has then reduced the popular doubt, and made popular perception changed from doubt to how to save people from radical ideas of Islam. Despite this, in later development, the public gives an "excuse" to Islamic radicalism, some by responding to it in a fairly positive way. This later public response is partly a result of the diverse strategies of Islamic radical groups in delivering their messages to the public, consisting of physical action and publication.

\section{The Roots of Islamic Radicalism}

Islamic radicalism has strongly colored the picture of Islam in contemporary Indonesia. The face of Indonesian Islam is identified with some radical Muslims-based groups, such as Front Pembela Islam 
(FPI, Islamic Defenders Front), Majelis Mujahidin Indonesia (MMI, Indonesian Mujahidin Council), Laskar Jihad (LJ, Jihad Paramilitary Troops), and Jama'ah Ikhwan al-Muslimun Indonesia (JAMI, Indonesian Ikhwan al-Muslimun Community). Even though Islamic radical groups do not have significant number in comparison with moderate ones, such as Nahdlatul Ulama' (NU, The Awakening of Muslim Scholars) and Muhammadiyah, they can draw the popular attention. ${ }^{2}$ These groups are prominent in the contemporary Indonesian Islam for their literal religious understanding and radical actions.

There are a lot of examples to show the radical actions of such groups. FPI has been involved in a number of raids and destruction of several cafés, discotheques, night clubs, gambling dens, and other socially "bad places", just as LJ has had an intimate connection to the jihadist actions in Maluku, Ambon and Poso of Central Sulawesi. In these conflicting areas, LJ has sent its militias to fight against Christians. Meanwhile, the Amir Majlis (the leader of the advisory board) of MMI, Abu Bakar Ba'asyir, is believed by such groups as Washington-based magazine, Time in its edition "Confession of an alQaeda Terrorist", ${ }^{3}$ Lee Kuan Yew in his address at the Conference on Asia Security by the International Institute for Strategic Studies, ${ }^{4}$ and above all by the US Bush administration, to be leading JI, a Muslim group believed to have networks throughout Southeast Asia, in particular Singapore and Malaysia, and to be allegedly linked to AlQaeda.

Much attention has been given to such Islamic radical groups. While MMI with Ba'asyir as its leader, as described by Huang, ${ }^{5}$ is allegedly responsible for the unsolved bombings in several places of Indonesia and the Philippines, LJ is believed to have played a significant role in the worsening of religious conflicts in several areas of Indonesia. Some commentators differently discern the involvement of LJ in such conflicts. Fealy notes that the sending of the Laskar

\footnotetext{
2 Azyumardi Azra, “Agama dan Otentisitas Islam,” Republika, 25 October 2002.

${ }^{3}$ See "Confession of an al-Qaeda Terrorist," Time Magazine, 23 September 2002.

${ }^{4}$ Sidney Jones, Al-Qaeda in Southeast Asia: The Case of the "Ngruki Network" in Indonesia (Jakarta/Brussels: International Crisis Group, 2002), p. 2.

5 Reyko Huang, "Al Qaeda in Southeast Asia: Evidence and Response," Terrorism Project, 8 February 2002, p. 1.
} 
militias to the areas of conflict, particularly in Maluku, resulted from the low capacity of the state to end the conflict and from the finding suggesting that Muslims were to be driven out from the areas as Protestant churches had plans to build Christian state consisting of Maluku, West Papua and North Sulawesi. ${ }^{6}$ Unlike Fealy, Marshall regards LJ as the responsible for the aggravation of the conflicts. According to Marshall, LJ is the cause of the deterioration of the conflicts as the coming of LJ militias in Maluku and Sulawesi hindered the attempts of reconciliation between the conflicting groups. Marshall also points out that LJ had plans to drive out all Christians and to establish an extreme version of Islamic law, particularly in Sulawesi. ${ }^{7}$

Such reported cases of Islamic radicalism might send a significant message that religious radicalism is frequently followed by violent actions. There is a parallel connection between religious radicalism and violence as the radicalism appears in the form of social resistance in accordance to its own religious understanding. There are, at least, three general tendencies of the radicalism. First, radicalism is perceived as a response towards the existing conditions, including assumption, idea, value, and institution regarded as deviant. Second, radicalism is not restricted to the form of such resistance, but also accompanied by an attempt to change the existing order with another one supposed to be better. Third, radicalism is equipped with a strong belief in a certain ideology and program, which can result in emotional reaction and violence. $^{8}$

Even though Islamic radicalism becomes a picture of contemporary Indonesian Islam, some commentators, while tending to come to the agreement that such Islamic radicalism is a new phenomenon for Indonesia, relate the phenomenon to the crisis suffered by the country. According to Hasan, Islamic radicalism, as a new phenomenon in Indonesia, is inseparable from the so-called multi-

\footnotetext{
${ }^{6}$ Greg Fealy, "Inside the Laskar Jihad: An Interview with the Leader of a New, Radical and Militant Sect," Inside Indonesia (January-March 2001), available at: http://www. insideindonesia.org/edit65/fealy.htm (Cited 15/04/02).

7 Paul Marshall, "Terror's Not New to Indonesia," Center for Religious Freedom, Freedom House (15 October 2002). Available at: [http://www.freedomhouse.org/religion/country/indonesia/Terror's $\% 20 \mathrm{Not}^{0} \% 20 \mathrm{New} \%$ to $\% 20$ Indonesia.htm] (Cited in $14 / 11 / 02)$.

${ }^{8}$ Khamami Zada, "Terorisme dan Radikalisme Agama," Media Indonesia, 18 Oktober 2002.
} 
dimensional crisis befalling the country since it started emerging in 1997 when Soeharto's regime was coming to the collapse. It seems to Hasan that Islamic radicalism had its moments when the country felt in the overwhelming crisis. ${ }^{9}$ In addition, Zada maintains that the fall of Soeharto provides Islamic radicalism with invaluable moments to accelerate its movement. ${ }^{10}$ The change of political leadership in Indonesia is likely to bring about the emergence of the alternative ideology in place of the previous one, and the ideology which seems to be more accurate to cover the movement of some contemporary Indonesian Muslims, according to Barton, is Islamism. The ideology which believes Islam can and should form the basis of political ideology, in Barton's view, ${ }^{11}$ can be the beginning of Islamic radicalism.

Certainly, the post-Soeharto era with its unsolved crises became a worthy moment for the emergence of Islamic radicalism. The phenomenon of Islamic radicalism became more visible in the postSoeharto era as the wide coverage of media towards their actions made their movements more influential. Van Bruinessen, while depicting Islamic radicalism as one of the most conspicuous new phenomena in contemporary Indonesian Islam, suggests that such Islamic radical groups had much power against the state authority at the time of the presidency of Abdurrahman Wahid. He gives an example that they often gained control of the streets under the unwillingness of the army and police to restrain them. ${ }^{12}$

Such analyses on the emergence of Islamic radicalism in Indonesia play an important role in looking at the wider phenomena of Islamic radicalism across Southeast Asia as a whole, especially when it has been already found that some Islamic radicalism in the region have been interconnected. Indonesia which has been noted for long time as being occupied by Moderate Muslims, and has the world's largest Muslim population, is now repeatedly claimed by several groups as a country with serious problems of Muslim terrorist and radical groups,

\footnotetext{
${ }^{9}$ Noorhaidi Hasan, "Islamic Radicalism and the Crisis of the Nation-State," Available at: http//www.isim.nl/newsletter/7/regional/1.html (Cited in 14/11/02).

${ }^{10}$ Khamami Zada, Islam Radikal: Pergulatan Ormas-ormas Islam Garis Keras di Indonesia (Jakarta: Teraju, 2002), 88.

11 Greg Barton, "Islamism and Indonesia: Islam and the Contest for Power after Soeharto," The Review (September 2002), p. 2.

12 Martin van Bruinessen, "Genealogies of Islamic Radicalism in Post-Soeharto Indonesia,” South East Asia Research, no. 2, vol. 10 (July 2002): p. 118.
} 
particularly in the aftermath of bomb blast in sites such as Kuta Bali and Marriot Jakarta. As pointed out by Fealy, ${ }^{13}$ such countries as the US, Singapore and Malaysia claim to have evidence of Indonesians leading offshore terrorist groups or of terrorists being based in Indonesia, and moreover, Singaporean senior minister Lee Kwan Yew, as indicated by Tempo, ${ }^{14}$ claimed that Indonesia was a 'hotbed of terrorism'. This intensifies the significance of analysis of why people become radicalised in the middle of the changing socio-political and economic situations within the course of the nation.

Some commentators have different opinions on the problem of why people become radical individuals. According to general view of terrorism, as suggested by Ramakrishna, ${ }^{15}$ people become radicalised by a nexus of political repression and crucial socio-economic deprivation; or in other words, they become so if the government conducts repressive measures towards the protests and aspirations of the society while it fails to provide them with, not to mention all, economic growth, proper jobs, and affordable education. From this view, an understanding can be drawn that radicalism results from two key points: political suppression by the government and socioeconomic downturn.

Such general view does not seem to be precisely the case in some Southeast Asian countries, however. Even though political repression and socio-economic decline have been the raison d'tre for the Islamic radicalism in Southeast Asia, there are other factors in the prevalence of radicalism: globalisation and Arabia. Islamic radicalism in Southeast Asia emerges, while in response to "political repression" and "poor governance", as a result of the global awareness of Muslims in the region of the developments in the Islamic world, which creates antiAmerican sentiment. Globalisation can be depicted as having poured more fuel on Islamic radicalism in Southeast Asia as Muslims of the region become aware that the problems facing the wider Islamic world resulting from a biased US foreign policy, while their national

\footnotetext{
13 Greg Fealy, "Is Indonesia a terrorist base?," Inside Indonesia (July-September 2002), available at: http://www.insideindonesia.org/ edit71/fealy1.htm (Cited 19 November 2002).

14 “Diakah Sang Imam?,” Tempo (3 November 2002), p. 25.

${ }^{15}$ Kumar Ramakrishna, "Jemaah Islamiah: Aims, Motivations and Possible CounterStrategies,” Perspective (October 2002), p. 1.
} 
governments have not done much to help change "Washington's policy mind-set".

Thus, Islamic radicalism in Indonesia is given rise by four major factors: political repression, poor governance, global awareness, and Arabia. It is frequently argued, as reported by International Crisis Group (ICG) in its "Indonesia Briefing" section, that the New Order regime's high suppression of political Islam contributed to the radicalisation of Muslim dissent. ${ }^{16}$ Moreover, the increase in Islamic radicalism is basically the outcome of the government failure to enforce the law and to solve socio-religious conflicts and the result of the abrupt decline of central government authority. Besides political struggle as well as poor governance as the roots, van Bruinessen adds that the present Islamic radicalism in Indonesia results also from global awareness, which paves the way for the establishment of transnational Islamic networks. ${ }^{17}$ In addition, Azra suggests that Islamic radicalism in Indonesia is closely related to the role of some Arab descendent figures in the groups of FPI, MMI, and LJ since they tend to take rigid and rigorous ways to come to their goals instead of persuasive and peaceful ones. ${ }^{18}$ Hefner admits that Islamic radicalism in Indonesia has come to its prominence with the significant contribution of financial assistance from Saudi Arabian authorities. ${ }^{19}$

Meanwhile, in Singapore and Malaysia, political repression and socio-economic decline do not seem to be the key factors of the Islamic radicalism. This is not to say that political and socio-economic reasons are not the factors of Islamic radicalism in both countries, but rather that there is another factor to be more apparent for it. Ramakrishna maintains that the most important factor and very basic cause of Islamic radicalism, as represented by JI extremism, in Singapore and Malaysia are ideological, not socio-economic or political. All the $31 \mathrm{JI}$ detainees in Singapore, according to Ramakrishna, are not "the children of poverty and despair", but they

\footnotetext{
${ }^{16}$ International Crisis Group, Indonesia: Violance and Radical Muslims (Jakarta/Brussels: International Crisis Group, 10 October 2002), p. 3.

${ }^{17}$ van Bruinessen, "Genealogies of Islamic Radicalism," p. 118.

18 Azra, "Agama dan Otentisitas Islam."

19 Robert W. Hefner, "Globalisation, Governance, and the Crisis of Indonesian Islam," (Unpublished paper presented to the Conference on Globalisation, State Capacity, and Muslim Self Determination, Center for Global, International, and Regional Studies, University of California-Santa Cruz, 7-9 March 2002), p. 24.
} 
are "gainfully employed" and own their homes encompassing HDB five-room or executive flats. In the matter of non-socio-economic and political factors of the Islamic radicalism in Malaysia, the roots can be traced to the background of its activists. Ramakrishna indicates that several leading activists of Islamic radical groups are the principals of schools, graduates and lecturers of universities. ${ }^{20}$ These kinds of job positions suggest a gainful employment, and show that the members of Islamic radicalism, who hold these job positions, occupy an upper level in the community in terms of the socio-economic status.

From the phenomenon of the Islamic radicalism in Indonesia, there is one significant feature that Islamic radicalism does not appear from zero point or without any affiliation to the others. Van Bruinessen maintains that Islamic radical groups in Indonesia can be traced to two roots: national and transnational networks. ${ }^{21}$ While national network refers to two relatively "indigenous" previous Muslim political movements, the Darul Islam (DI) movement and the Masyumi Party, transnational network relates to a number of such more recent transnational Islamic links as the sponsor groups, which are identified by van Bruinessen ${ }^{22}$ with Saudi Arabia, Kuwait, and Pakistan.

From such a perspective, the DI movement and the Masyumi Party have inspired the activists of current Islamic Radicalism in Indonesia, and thus have occupied a certain place in their hearts. Having been ordered to dissolve itself in early 1960s, according to van Bruinessen ${ }^{23}$ and ICG, ${ }^{24}$ Masyumi transformed its political struggle then into, one of the things, the missionary efforts among Indonesian Muslims under the name of Dewan Dakwah Islamiyah Indonesia (DDII, the Indonesian Dakwah Council) in 1967. The two prominent figures, which are claimed to be leading JI, Ba'asyir and Sungkar, are indicated by van Bruinessen to be well connected to DDII circles. ${ }^{25}$ Van Bruinessen also indicates that one of the most active Islamic radical groups, MMI, in which Ba'asyir used to occupy the position of

\footnotetext{
${ }^{20}$ Ramakrishna, "Jemaah Islamiah,” pp. 1-3.

${ }^{21}$ van Bruinessen, "Genealogies of Islamic Radicalism, p. 118.

22 Ibid., p. 149.

23 Ibid., p. 122.

${ }^{24}$ International Crisis Group, Indonesia: Violance and Radical Muslims, p. 11.

${ }^{25}$ van Bruinessen, “Genealogies of Islamic Radicalism, p. 129.
} 
leadership, encompasses the sections of the DI movement of the foregoing decades. ${ }^{26}$ Hefner also points out that among those in MMI organisation's rank are individuals associated with the DI group. ${ }^{27}$ The connection of the alleged terrorist organisation, JI, to the DI movement, according to Jones, ${ }^{28}$ has gained justification from the intimate relationship between Ba'asyir and Sungkar and Kadungga, a son in law of Kahar Muzakkar, the leader of DI movement in South Sulawesi.

In sum, globalisation has met with localisation ("glocalisation") to become two contributing factors for Islamic radicalism in Southeast Asia. Globalisation has raised the awareness of Muslims of the global situation facing Islamic world. This awareness has generated Muslims' reaction to the existing situations they face, using lots of their possible religious and financial resources. This condition has been devastated by the reduced capacity of the state where Muslims stay in, coupled with socio-economic downturn, to deal with radicalism and violation within the country.

\section{The Unresolved Jama'ah Islamiyah as a Radical Group}

Jama'ah Islamiyah is claimed to be an organisation with an ultimate goal of establishing a great Islamic state in Southeast Asia. As a result of the alleged Indonesian Muslim figures behind JI, the issue of JI in Indonesia has become the subject of wide debate. The Indonesian prominent figures are suspected of having leading roles in the organisation, and thus JI is presumably thought to exist in Indonesia. It was not until the end of 2003 that commentaries on the issue can be classified into having two approaches. The first approach sees that JI really exists in Indonesia, just as the second approach views that $\mathrm{JI}$ in Indonesia is only a fictitious organisation blown up by the political campaign of other countries. Both approaches have their own rationale, and thus they give rise to different consequences in terms of analysis of the alleged terrorist group, JI.

The approach, which sees that JI has really a presence in Indonesia, relates the emergence of JI to the auspices of the

\footnotetext{
${ }^{26}$ Ibid., p. 144.

${ }^{27}$ Hefner, "Globalisation, Governance, and the Crisis," p. 21.

28 As quoted in "Sidney Jones: Hambali Adalah Petinggi Al-Qaidah," Tempo (3 November 2002), p. 53; “Jejak Ba'asyir di Sungai Manggis,” Tempo (3 November 2002), p. 28.
} 
Indonesian military. One of the proponents of this approach, Sidney Jones says that JI in Indonesia, which is allegedly responsible for several terrorist acts in Southeast Asia, was established by the Indonesian military in the beginning of the 1970s. The establishment of this organisation, according to Sidney Jones, was mainly to accommodate the political interests of Muslims in the era of Soeharto, and at the same time to manipulate it as a 'rubberstamp' for labelling any Islamic movement fundamentalist groups. With this labelling, the government had a reason then, as indicated by Sidney Jones, to eradicate and combat the movements that allegedly bring a danger to the country. ${ }^{29}$

The evidence exploited by such an approach to convince the existence of JI in Indonesia is taken from the District court documents, from which the term "Jama'ah Islamiyah" was found in Indonesia for the first time. As explicitly suggested by Sidney Jones, the term "Jama'ah Islamiyah" did not appear until to be found in the court documents from the 1980s, one of the things is the Sleman District document under the title "Berkas Perkara Tersangka Abdullah Sungkar [Case Document of the Alleged Abdullah Sungkar]",30 However, according to Tempo, there is another court document found earlier than the document of Sungkar's trial to support the claim of the presence of JI in Indonesia. This document is the Medan District Court document of 1978 on charges of Gaos Taufik, the leader of Komando Jihad (Jihad Command), which states, as reported by Tempo, that Taufik had taken Abdullah Umar's oath of loyalty to the JI in establishing a state based on Islamic law. ${ }^{31}$ From this evidence, it is clearly shown that the term "Jama'ah Islamiyah" is acknowledged for the first time through the documents of the court, which contain charges on the alleged figures of Islamic radicalism.

\footnotetext{
29 As quoted in "Jemaah Islamiyah Dibentuk oleh Militer Indonesia?," 13 August 2002, available at: [http://www.detik.com/peristiwa/2002/08/13/20020813-055812.shtml] (Cited 06/11/02).

${ }^{30}$ In this document, it is told the term "Jama'ah Islamiyah" comes from Abdullah Sungkar. He used the term to call his organisation. Sungkar informed the court that as he received information from newspapers that the members of Jama'ah Islamiyah have been detained in Medan, he was certain to go to Pondok Ngruki for security reason. See Sidney Jones, Al-Qaeda in Southeast Asia: The Case of the "Ngruki Network" in Indonesia (Jakarta/Brussels: International Crisis Group, 2002), pp. 5-6.

${ }^{31}$ See “Diakah Sang Imam?,” p. 25.
} 
A criticism has been directed, however, towards such an approach. The evidence to show the existence of JI solely through the court document without any sufficient investigation towards political atmosphere of the time is believed to be misleading. Supriyono, a senior journalist of the Indonesian daily newspaper, Republika, criticises such an approach, saying that the allegation of JI to exist in Indonesia based only upon the finding of the term "Jama'ah Islamiyah" from the court document of the trial process of Abdullah Sungkar needs to be further investigated as the emergence of the term resulted only from the indictments of the prosecutor in later 1970s and early 1980s. Any reference to the political cases of Muslims at this period, according to Supriyono, must be carefully conducted with an analytically close and careful observation of the political relations of Islam and the state in which the New Order regime conducted very strong political repression on Muslims. Under this political repression, what to be the indictment of the prosecutor, as apparent in other cases, is likely to be also what to be the scenario of the state intelligence body. The trial of Abdullah Sungkar at this period went under this situation with the result that the term "Jama'ah Islamiyah", as indicated by Supriyono, might appear in Sungkar's confession under the direction of the intelligence body. 32

Meanwhile, the approach, which views that JI in Indonesia is only a fictitious organisation, relates the issue to the familiarity of its name and the political campaign of other countries. Some Indonesian commentators tend to follow this approach, maintaining that as a Muslim organisation, JI is not well acknowledged by Indonesians; most Indonesians having no prior knowledge of the existence of this organisation. Alfitra Salamm, a researcher from LIPI (Lembaga Ilmu Pengetahuan Indonesia/Indonesian Institute of Science), for example, states that JI is not a real, but only a fictitious organisation set up by Malaysia and Singapore governments to silence the criticism of Islamic radical groups in their respective countries. ${ }^{33}$

\footnotetext{
32 As quoted in Institut Studi Arus Informasi (ISAI), "Liputan Media Tentang Bali: Mana Jurnalisme Mana Propaganda?," (Seminar Proceeding by ISAI and Majalah Pantau, Jakarta, 7-8 November 2002).

33 As quoted in "Peneliti LIPI: JI Organisasi Maya Buatan Malaysia dan Singapura," Detikcom, available at: [http://www.detik.com/peristiwa/2002/10/30/20021030-065421.shtml] (Cited in 06/11/02); "Jamaah Islamiyah yang Cuma Bualan," Forum Keadilan, No. 3 (10 November 2002): p. 16
} 
Certainly, if the parameter used to relate the organisation of JI in Southeast Asia to Indonesian figures is only based on the government claims and the confession of detainees, several Indonesian figures are the subjects of such allegations. In Malaysia, for example, JI, as reported by The Malay Mail, was claimed to be established by two Indonesian clerics, Ba'asyir and Riduan a.k.a. Isamuddin Hambali at the time of their status of exile in Malaysia. JI is allegedly to exist through the Kumpulan Militan Malaysia (KMM), an organisation regarded, according to The Malay Mail, as the offshoot or the local branch of the JI, which had plans to establish a pan-Islamic state including Indonesia, Singapore, southern Philippines, Malaysia, and Brunei. ${ }^{34}$ The allegation of there being links between KMM and JI has also been made by the Singapore government. According to Fealy, like in Malaysia, officials in Singapore claimed there were links between the two organisations. This allegation was followed by the arrestment of several figures in the period of mid 2001 to early 2002.35 All the detainees, according to Internal Security Department (ISD) of Singapore, confessed that such four Indonesian Muslim figures as Ba'asyir, Hambali, Abu Jibril or Mohammad Iqbal bin Abdul Rahman, and Faiz bin Abu Bakar Bafana are their JI leaders. ${ }^{36}$

The public doubt about the existence of $\mathrm{JI}$ as a radical Islamic group in Indonesia has been decreased since the end of 2003. Since then, the issue has been no longer about whether or not JI exists in Indonesia. Rather, public debate goes to an issue of how to deradicalise the communities, or how to secure people from radical ideas of Islam. This shift of public discourse is a result of the success of the police in proving allegations against Imam Samudra, Amrozi, and Ghufron as the masterminds of the 2002 Bali Bombing. The public goes further to be less doubtful of the existence of $\mathrm{JI}$ in Indonesia following the execution of these three Bali bombers on 9 November 2008.

Another factor of the lessening of the public doubt about the existence of $\mathrm{JI}$ as a radical group in Indonesia is the actions by its

34 "Bali Bombings: Mastermind with Local Links," The Malay Mail (19 November 2002), available at: [http://www.mmail.com.my/Current News/MM/Monday/Frontpage/20021118094632] (Cited 19/11/02).

35 Fealy, "Is Indonesia a terrorist base?," p. 1.

36 "Stemple JI dari Singapura," Tempo (10 November 2002), p. 37; "Jejak Ba'asyir di Sungai Manggis," Tempo (3 November 2002), p. 30. 
activists which have manifested in different ways. Their actions are varied from physical to ideological, which eventually show their energetic activism in the public. As elaborated below, the activists of this radical group have implemented different strategies in sending their messages to the general public audience, from physical attacks to publication, and then from publication to another kind of physical action. The media widely covered what the activists of this radical group have conducted in their presence in the public sphere. As a consequence, public attention has been bombarded with the energetic activism of the proponents of this radical group along with other wings of the radical Muslims. The actions of the radical Muslim activists have, in due course, attracted public attention.

Even though the number of radical Muslims remains small in Indonesia compared to that of moderate Muslims, the popular perception about their way of distributing their messages through physical actions needs a thorough analysis. This is because people, as a recent survey reported by Kompas suggests, do not intend to be entirely opposed to radical Muslims' actions. The survey is so illustrative as follows:

Table 1: Perception of Terrorism

\begin{tabular}{ll}
\hline Items of Perception & $\%$ \\
\hline Supporting suicide bombing as part of jihad & $18.1 \%$ \\
$\begin{array}{l}\text { Favouring Amrozi's and Samudera's way of physical action as a } \\
\text { required jihad }\end{array}$ & $6.7 \%$ \\
$\begin{array}{l}\text { Agreeing, Osama-led al-Qaedah's strategies against US need full } \\
\text { supports }\end{array}$ & $59.1 \%$ \\
$\begin{array}{l}\text { Agreeing for physical attacks against the Kuffar for da'wah } \\
\text { purposes }\end{array}$ & $30.5 \%$ \\
\hline
\end{tabular}

Source: a research presented by Nasaruddin Umar (Director General of Guidance for Muslims, MORA), to the Conference on CounterTerrorism in Nusa Dua, Bali, as quoted in "Penanggulangan Terorisme: Mulailah dari Komunitas Terkecil," Kompas (22 October 2010).

Such a range of perception seems to result particularly from strategies developed by the activists of radical Muslim groups. What has been conducted by JI activists need to be the case of analysis in grasping a better sense of the diverse strategies of these groups. Activists from these groups develop different strategies, from physical action to publication, and from publication to another physical action. These strategies add new types to a common strategy previously 
developed from oral preaching to physical action. The following subsection particularly discusses two strategies, from physical action to publication, and from publication to another physical action.

\section{Ar Rahmah Media Network: From Physical Action to Publication}

Jihadmagz is a bimonthly Islamic magazine established by Ar Rahmah Media Network, based initially in Pamulang and currently in Bintaro, Tangerang, Banten. Owned and managed by Muhammad Jibriel Abdul Rahman (more popularly known as Jibriel), Ar Rahmah Media Network is itself a publishing house with a huge production of jihad-oriented publications. It produces these publications in an active way in Indonesia so that people can easily find its products, from pamphlets, books, video CDs, to magazines, in the market. Its success in producing jihad-oriented publications has inspired other publishing houses, such as Muqowama and Bumi Karya Media, to follow its example. ${ }^{37}$

Jihadmagz was first launched on 1 March 2008 during the $7^{\text {th }}$ Islamic Book Fair in Istora Senayan, Jakarta. It was launched by two leading jihad activists in Indonesia and the wider Southeast Asia region, Ba'asyir and Muhammad Iqbal Abdul Rahman alias Fihiruddin (more popularly known as "Abu Jibriel"). Ba'asyir was himself previously the amir or top leader of the MMI and recently the amir of Jama'ah Anshorut Taubid (literally "the community of defenders of Islamic theology"). As his name indicates, Abu Jibriel is, in reality, the father of Jibriel, the owner as well as executive director of the magazine.

Jihadmagz is an attractively printed Islamic magazine which pays special attention to the raising of the issue of jihad among local communities in Indonesia. It is second to none amongst Islamic magazines specialising in the dissemination of jihad ideas with its strong accentuation and orientation towards the raising of Muslims' religious-ideological awareness of waging physical war against the West and the infidels. The wording of the advertisement for its launching even claimed that it was "the first jihad magazine in the world".

\footnotetext{
${ }^{37}$ International Crisis Group, Indonesia: Jemaah Islamiyah's Publishing Industry, Asia Report No.147/28 February 2008 (Jakarta \& Brussels: International Crisis Group, 2008), p. 10.
} 
Some comparison can be made between Jihadmagz with other Islamic magazines with a similar ideological bent such as Khilafah Magazine (more commonly referred to as K-Mag) and An-Najah. K-Mag is published by the Bogor-based Pustaka Thariqul 'Izzah. An-Najab is published by the Solo-based Forum Studi Islam An-Najab (An-Najah Forum for Islamic Studies). In the eyes of these latter two magazines, the idea of jihad does not refer to the sense of physical jihad or physical war against the West and the infidels. Jibadmagz, however, strongly and staunchly promotes these ideas, as elaborated below. ${ }^{38}$

The establishment of Jihadmagz marks a new trend in public expression among the Islamic jihadist movement in Indonesia, from physical actions on the ground to publications. In the past, jihad activists had long been concerned with involving themselves in physical action against Westerners and non-believers. The Ambon conflict between Muslims and non-Muslims in the period 1999-2002 was an example of involvement in jihad activism, which was later reproduced in the forms of a video $\mathrm{CD}$. Recently, they reoriented their activism from physical action on the ground of conflict areas to print publication. This reorientation is due partly to the anti-terrorism campaign conducted energetically by the government. The production of Jihadmagz is a striking example of this reorientation.

The phenomenon of the growing interest among jihad activists in print publication can be taken as another kind of obvious evidence to support the argument that print publication has a comparative advantage in constructing a certain ideological belief among the people. Through print publication, people not only can discover ideas and views of Islam, but also can reflect upon their meanings. This opportunity for reflection allows people not only to have a better grasp of Islamic ideas or views, but also to obtain a deep understanding of both emotional and doctrinal aspects of those Islamic ideas or views. So, the interplay between print publication and consumers works well. Print publication extends itself to attract not only its own captive audience but also the non-captive audience. It is one reason that print publication not only accommodates the market but also creates a new market or audience.

\footnotetext{
${ }^{38} \mathrm{It}$ is in this strong and steadfast sense of jihad that the claim made by ICG that there were already several jihad magazines preceding Jihadmagz in Indonesia, including $A n$ Najah, is baseless. For more information about the ICG's claim, see International Crisis Group, Indonesia: Jemaah Islamiyah's Publishing, p. 10.
} 
The concept of "jihad media" promoted by Ar Rahmah Media Network and exemplified by Jihadmagz cannot be separated from the activism of Jibriel himself (b. 1984). Jibriel is the oldest of the eleven children of Muhammad Iqbal Abdul Rahman alias Fihiruddin alias "Abu Jibriel". Abu Jibriel is himself a prominent jihad activist who lived for many years in Malaysia with other da wah and jihad activists such as Abdullah Sungkar and Ba'asyir. ${ }^{39}$

Jibriel's partnership with Agus Suhendra and M. Fachry contributed to the further development of Jibadmagz and other products of so-called "jihad media" by Ar Rahmah Media Network. Suhendra was working for a distributing company of Hollywood movies based in the Mangga Dua Complex, Central Jakarta. Fachry was a senior editor of the well-established Islamic book publishing house with a strict-conservative ideology, GIP. Jibriel gained knowledge relating to marketing, circulating, and distributing the products of jihad media from Suhendra. Likewise, he obtained similar knowledge of editorship matters from Fachry. In organising Ar Rahma Media Network in general and Jihadmagz in particular, Jibriel serves as the idea creator in addition to his capacity as the owner and as the executive director, just as Suhendra and Fachry are respectively the marketing manager and editor-in-chief. ${ }^{40}$

The establishment and early operation of Jihadmagz resulted initially from self-funding in the sense of personal financing by Jibriel's family, and was later supported by financial sources with no usury principles. As Jibriel points out, the financial source for the establishment and initial operation of Jihadmagz was his father, Abu Jibriel. The so-called "social trust" Jibriel obtained from the printing company and his Ar Rahmah crews, allowing for delayed payment for production cost and job salary, is another kind of so-called "initial capital". Jihadmagz also took much advantage of other financial sources. Since it considers usury as haram (legally unjustifiable), the magazine made use of financial support from individuals in Jakarta as the additional capital under the economic model of mudarabah ("profit-sharing"). ${ }^{41}$ So,

\footnotetext{
${ }^{39}$ Ibid., p. 10.

40 Interviews with Jibriel, Istora Senayan, Jakarta, 04 March 2008; Jibriel, Bintaro, Tangerang, Banten, 25 April 2008.

41 Interview with Jibriel, Bintaro, Tangerang, Banten, 25 April 2008. By definition, mudarabab is a principle or an arrangement for a business contract between two parties, the first as the investor (sabib al-mal) and the other as the entrepreneur (mudarib), which
} 
Jibadmagz relied more on individual rather than institutional sources such as banks for supporting its operation.

Jihadmagz is oriented to middle-class consumers, allowing for greater impact. The reason, according to the magazine, is that the middle class has an important role in leading change. By segmenting this market level, the ideas of jihad can be more easily disseminated and imparted to society. ${ }^{42}$ For this reason, production of Jibadmagz is exclusive. The magazine is produced in full colour and hard paper. It sells at an expensive price, Rp. 45,000, in comparison to other wellestablished news magazines such as Tempo which sells for Rp. 22,500.

For marketing purposes, the exploitation of jihad ideas and practices as materials for publication by Jihadmagz is not without reason. Especially during the global campaign against (Islamic) terrorism and the jihadist movement, people around the world kept an eye on the jihad movement in every single part of the globe. Indonesia was no exception. Especially following Bali Bombing I which killed no less than 202 people and injured hundreds of others, the Bali Bombing II (1 October 2005) with 23 dead and 196 injured, and the Kuningan Bombing in Jakarta (9 September 2004) which killed 9 people and injured more than 100 others, some repressive political measures by the government have been taken against the militant da'wah-cum-jihad movement across Indonesia. These repressive political measures have been actively conducted under the auspices or supports of foreign governments such as those of Australia and the US.43

Under such a difficult situation, not only did those militant da ${ }^{`}$ wahcum-jihad activists modify and diversify their activities into various forms such as publications, but other Muslims, especially harakah activists, also started to seek for more information about the "fundamentalist-militant-jihadist-hardliner" Islamic movement. As a result, an Islamic magazine publication focusing on this "fundamentalist-militant-jihadist-hardliner" Islamic ideology began to emerge and attract popular attention. Jihadmagz captured this situation as the potential market for its publications. It appears consistent with,

requires profit and loss sharing to be determined during the agreement of the contract. For more information, see Muhammad Ayub, Understanding Islamic Finance (Hoboken: John Wiley \& Sons, 2007), pp. 320-328.

42 Interview with Jibriel, Bintaro, Tangerang, Banten, 25 April 2008.

43 See, for example, AusAID, Counter-Terrorism and Australian Aid (Canberra: AusAID/Australian Government, 2003), especially p. 6. 
and committed to, the production and dissemination of this Islamic ideology within its publications throughout this time.

In the market, in fact, Jihadmagz performs quite well. The first issue in March 2008, for example, was produced in 5,000 copies, but sold within less than two months 4,000 copies. ${ }^{44}$ As a newly established Islamic magazine in a period of increasingly tight market competition, Jihadmagz can be regarded as highly saleable. In comparison, Madina, a Jakarta-based Islamic magazine established a year earlier than Jihadmagz, is printed in as many as six to eight thousand copies per issue, but sells on an average only 35 percent of the whole volume of production for each edition..$^{45}$ Even though it is a newly established magazine, Jihadmagz has performed well with high saleability in the market.

\section{Renewal Strategy: From Publication to another Physical Action}

Another reorientation of public expressions by radical Muslims emerges when they feel confident enough with their own organisational plans. This reorientation leads them to shift from the making use of publication as a means of their meaning-making and message-producing to another kind of physical action. This shift of strategy seems to be implemented following the continuing consolidation among the activists of radical Muslim groups during the so-called "ceasefire" period where publication becomes a key instrument one the one hand, and as a response to the detaining of several radical Muslim activists on the other hand.

One of the most striking examples which can be taken as evidence to mark the shift of strategy from publication to another physical action is the robbing of CIMB Niaga Bank in Medan on 18 August 2010. This rob action has fuelled the war against the radical Muslim activists by the police. Attempts by the police to chase the culprits of the bank rob has been undertaken in areas in Sumatra ranging from Medan to other provinces, and even to other provinces including Java. From the perspective of the police investigation, several figures alleged to have been responsible for the bank rob in question are activists having close relationship with JI-affiliated individuals. Some, in the eyes to the police, are part of the terorism network with a number of jihadist training experiences held in Aceh and West Java. They are

\footnotetext{
${ }^{44}$ Interview with Jibriel, Bintaro, Tangerang, Banten, 25 April 2008.

${ }^{45}$ Correspondence with Ade Armando, the editor-in-chief of Madina, 15 July 2008.
} 
under the coordination of Mustofa (better known as Abu Tholut). Abu Tholut was himself put in jail for four years and half long for terrorism acts. After his release, he was believed by the police to be involved again in the fields of terrorism. He was then captured by anti-terrorism police force of Densus 88 in Kudus, Central Java, on 10 December 2010 for being suspected to have a connection to the perpetrators of the CIMB Niaga Bank robbers in Medan.

Such a reorientation from publication to another kind of physical action adds another kind to the strategies developed by radical Muslims in contemporary period in Indonesia. As suggested earlier, in the past, jihad activists had long been concerned with involving themselves in physical action against Westerners and non-believers. In other words, physical action represents the early strategy exploited in their public expression. In later development, jihad activists made use of publication as an additional means for meaning-making and message-producing.

The phenomenon of the growing interest among jihad activists in shifting the strategy from publication to another physical action can be taken as another kind of obvious evidence to support the argument that Islamic radicalism is not a make-up story. The using of diverse strategies is just to show that they exist among communities. These different strategies just follow the growing socio-political situation of the country and the maturity of the consolidation results among the radical jihadist activists.

\section{Conclusion}

The phenomenon of Islamic radicalism has been quite prominent in the regional development of Southeast Asia, particularly in Indonesia. As a result, Indonesia turns to be the subject of the allegation of the hotbed of radicalism and terrorism. Four factors have contributed to the rise of Islamic radicalism In Indonesia, including the regime's political repression, crucial socio-economic deprivation, globalisation, and the so-called "Arabia" support. Also, in this country Islamic radicalism appears in connection to two main roots: national roots tracing back to the previous Islamic movement and party in the early history of Indonesia, and transnational networks referring to a number of recent transnational Islamic links as the sponsor groups.

The diverse strategies developed by activists of Muslims radical groups contribute to the expansion of ideas distribution to wider audience. The reason is that people are given more opportunity to 
reflect upon the meaning of the action conducted by activists of radical Muslim groups, either through publication or physical action. As a result, even though their involvement in physical attacks against other people remains a public concern, popular Muslims' perception about the activism of radical Muslims do not entirely tend to be in opposition to the deadly physical attacks most likely conducted by jihad activists. This kind of perception can be assumed to be a consequence of the energetic activism of those radical Muslims exploiting such different strategies.

Such a kind of public perception proves to have led to the shift of popular understanding about Islamic radicalism from the doubt of the existence of one of its wings, JI, to the increasingly positive responses towards the struggles of radical Muslims. Rather than maintaining their doubt of the existence of JI, people start to formulate their ideas to deal with the struggles of Islamic radicalism. The bombardment of information and messages through such different strategies (publication and physical action) has imparted a message to the public that JI, and other radical Muslim groups, has attracted popular attention, and hence becomes a popular concern. Global geopolitics and the increasing conservative understanding of Islamic doctrines of jihad pose a new subject of study, and therefore deserve a thorough analysis in order to get a better comprehension of such a growing public perception. Kinds of research on these two issues appear to be significant to undertake. []

\section{References}

\section{Books and Articles}

AusAID. Counter-Terrorism and Australian Aid. Canberra: AusAID/Australian Government, 2003.

Barton, Greg. "Islamism and Indonesia: Islam and the Contest for Power after Soeharto." The Review (September 2002), p. 2.

Bruinessen, Martin van. "Genealogies of Islamic Radicalism in PostSoeharto Indonesia." South East Asia Research, no. 2, vol. 10 (July 2002): 117-154.

Hefner, Robert W. "Globalisation, Governance, and the Crisis of Indonesian Islam." Unpublished paper presented to the Conference on Globalisation, State Capacity, and Muslim Self 
Determination, Center for Global, International, and Regional Studies, University of California-Santa Cruz, 7-9 March 2002.

Huang, Reyko. "Al Qaeda in Southeast Asia: Evidence and Response." Terrorism Project, 8 February 2002.

Institut Studi Arus Informasi (ISAI). "Liputan Media Tentang Bali: Mana Jurnalisme Mana Propaganda?.” Seminar Proceeding by ISAI and Majalah Pantau, Jakarta, 7-8 November 2002.

International Crisis Group, Indonesia: Jemaah Islamiyah's Publishing Industry, Asia Report No.147/28 February 2008. Jakarta \& Brussels: International Crisis Group, 2008.

--------. Indonesia: Violance and Radical Muslims. Jakarta/Brussels: International Crisis Group, 10 October 2002.

Jones, Sidney. Al-Qaeda in Southeast Asia: The Case of the "Ngruki Network" in Indonesia. Jakarta/Brussels: International Crisis Group, 2002.

Muhammad Ayub. Understanding Islamic Finance. Hoboken: John Wiley \& Sons, 2007.

Ramakrishna, Kumar. "Jemaah Islamiah: Aims, Motivations and Possible Counter-Strategies.” Perspective (October 2002).

Zada, Khamami. Islam Radikal: Pergulatan Ormas-ormas Islam Garis Keras di Indonesia (Jakarta: Teraju, 2002).

\section{Newspapers}

"Confession of an al-Qaeda Terrorist." Time Magazine, 23 September 2002.

"Jamaah Islamiyah yang Cuma Bualan." Forum Keadilan, No. 3 (10 November 2002), p. 16.

"Sidney Jones: Hambali Adalah Petinggi Al-Qaidah." Tempo (3 November 2002), pp. 52-54.

Azra, Azyumardi "Agama dan Otentisitas Islam.” Republika, 25 October 2002.

Zada, Khamami. "Terorisme dan Radikalisme Agama." Media Indonesia, 18 Oktober 2002.

“Diakah Sang Imam?.” Tempo 3 November 2002, p. 25. 
“Jejak Ba’asyir di Sungai Manggis.” Tempo (3 November 2002): pp. 2830.

“Stemple JI dari Singapura." Tempo, (10 November 2002), p. 37.

\section{Internet Sources}

"Bali Bombings: Mastermind with Local Links." The Malay Mail (19 November 2002), available at: [http://www.mmail.com.my/ Current News/MM/Monday/Frontpage/20021118094632] (Cited 19/11/02).

"Jemaah Islamiyah Dibentuk oleh Militer Indonesia?." 13 August 2002, available at: [http://www.detik.com/peristiwa/2002/08/13/ 20020813-055812.shtml] (Cited in 06/11/02).

"Peneliti LIPI: JI Organisasi Maya Buatan Malaysia dan Singapura." Detikcom, available at: [http://www.detik.com/peristiwa/2002/ 10/30/20021030-065421.shtml] (Cited in 06/11/02).

Fealy, Greg. "Inside the Laskar Jihad: An Interview with the Leader of a New, Radical and Militant Sect." Inside Indonesia (JanuaryMarch 2001), available at: http://www. insideindonesia.org/ edit65/fealy.htm (Cited in 15/04/02).

Greg Fealy, "Is Indonesia a terrorist base?." Inside Indonesia (JulySeptember 2002), available at: http://www.insideindonesia.org/ edit71/fealy1.htm (Cited 19 November 2002).

Hasan, Noorhaidi. "Islamic Radicalism and the Crisis of the NationState." Available at: http//www.isim.nl/newsletter/7/ regional/1.html (Cited 14/11/02).

Marshall, Paul. "Terror's Not New to Indonesia." Center for Religious Freedom, Freedom House (15 October 2002). Available at: [http://www.freedomhouse.org/religion/country/indonesia/Te rror's $\% 20$ Not $\% 20$ New $\%$ to $\% 20$ Indonesia.htm

(Cited 14/11/02).

\section{Interviews and Correspondences}

Correspondence with Ade Armando, the editor-in-chief of Madina, 15 July 2008.

Interview with Jibriel, Bintaro, Tangerang, Banten, 25 April 2008.

Interview with Jibriel, Istora Senayan, Jakarta, 04 March 2008. 